\title{
Abject Desires in Lisa See's Peony in Love
}

\author{
CHIN KOON POH \\ University Putra Malaysia, Malaysia \\ carolchin@live.com \\ MOHAMMAD EWAN AWANG \\ Department of English, \\ Faculty of Modern Languages and Communication, \\ University Putra Malaysia, Malaysia \\ ARBAAYAH ALI TERMIZI \\ Department of English, \\ Faculty of Modern Languages and Communication, \\ University Putra Malaysia, Malaysia \\ FLORENCE TOH HAW CHING \\ Department of English, \\ Faculty of Modern Languages and Communication, \\ University Putra Malaysia, Malaysia
}

\begin{abstract}
The establishment of the Manchu led-Qing dynasty in 1636 led to the continuation of Confucianism as the dominant belief system in China. Based on these Confucian principles of patrilineality and patrilocality, women were expected to portray exemplary feminine virtues that required them to remain subservient and obedient to the men in her family. This oppressive practice placed women lower in the hierarchy as, unlike men, they were denied the means and avenue to express their subjectivities and, consequently, had to repress their desires to conform to a collective identity. Female desires are viewed as a form of abject as they do not conform to the female codes of behaviour assigned by the patriarchal system. To follow their desires would mean going against the gender norms of the society. As such, women's desires are attributed abject qualities due to their ability to disrupt the boundaries of the dominant system and are thus subject to censorship. Lisa See's Peony in Love (2007) depicts the struggles and predicament of Chinese women who had to repress their desires due to their gender. Using Julie Kristeva's concept of the abject, this study intends to examine how the female protagonist, Peony negotiates her position within the patriarchal setting to reclaim her sense of identity. According to Kristeva, the abject can distort boundaries due to its transgressive nature. For this reason, the study will set out to identify representations of abject desires and their implications on Peony. This study argues that it is through these representations of abject desires that enable Peony to subvert the patriarchal boundaries and reclaim her sense of identity.
\end{abstract}

Keywords: abject; Julie Kristeva; Chinese culture; gender; Lisa See

\section{INTRODUCTION}

Lisa See's Peony in Love (2007) is a tragic and haunting novel that chronicles the experiences of Chinese women in the parallel world of the living and the Chinese afterlife. Set in between the late $17^{\text {th }}$ and $19^{\text {th }}$ century China, this novel offers an insight into the predicaments of Chinese women in a male-dominated society. The desire to be heard and the pursuit of freedom seemed far-fetched as Chinese women during that era were silenced by a system that favoured a dominant male discourse. This novel follows the journey of the main female character, Peony, as she attempts to reclaim her subjectivity within the gendered boundaries of the Qing society. In pursuit of her private interests and goals, Peony must negotiate between her personal values and existing cultural ones. This demonstrates a constant and conflicting desire to become a subject on her own terms. To begin with, both subjectivity and identity are culturally constructed notions. Every individual is transformed into a subject upon one's immersion into 
the culture. For this reason, Sheikh (2017) explains that subjectivity is not universal nor a fixed or timeless entity. On the same note, identity is intertwined with notions of culture, politics, power, language, and gender (Montashery, 2012).

Having said that, Peony's desire to be a subject on her own terms may come with its own set of challenges. This is because dominant patriarchal societies have their own set of culturally constructed expectations, norms, and roles for both gender identities. For instance, the exclusion of women as speaking subjects has been practised by many patriarchal societies. The perspective that women should be prevented from expressing their subjectivity due to their gender has resulted in a history of silence among women for many centuries. In the context of the patriarchal Qing society, women were viewed as abject figures as they were isolated, marginalised, and silenced from the public sphere. The lack of agency and autonomy in both the public and private spheres confined Chinese women to a life-long arrangement of dependency. They were also impelled to uphold female virtues and subjected to restricting gender roles. Theiss (2002) writes that "[i]n this context, the virtue of women - including not only sexual chastity but also modesty, obedience to family superiors and propriety in manners, speech, and dress - became a touchstone of social quality, moral refinement, and cultural identity" (p. 48). As time went by, Chinese women regarded their fate as customary and eventually adopted a self-image that exemplifies the lies of inferiority and inadequacy.

In Peony's case, these oppressing factors of gender and culture clash with her perception of love and desire. Her love for her supposed husband, Wu Ren, her desire to choose her own destiny and her passion for reading and writing, were restricted and shunned upon during her time as these abject notions of desire were considered as a challenge to the moral and cultural conventions of the patriarchal Qing society. In relation to this, $\mathrm{Li}$ (2009) points out that Chinese women who indulged in the literary discourse were viewed negatively as based on the Confucian prescription of gender roles, women were not supposed to partake in a world beyond their inner spheres. Furthermore, Chinese women were disabled from and deemed as incapable of making decisions concerning their lives. Weighty decisions that concern their marriage and well-being were made by her superiors. Denied the right to decide for themselves, all they could do was to abide by the rules and decisions imposed upon them (Ciarcinska, 2019). Due to these limiting and discriminating cultural practices, Peony has no other option but to repress her desires since she is no longer able to relate to herself and those around her. Upon death, Peony returns as a ghost, with the ability to haunt and visit both the living and the dead, but she is still denied rest. The reason for this, as highlighted by Chinese metaphysics, is that pent-up emotions that individuals withhold while they were still alive can result in unfulfilled desires and grievances. To further elucidate on this point, Zeitlin (2007) explains that a ghost in the Chinese context, "literally becomes the outward manifestation and perpetuation of the invisible emotional and physical forces at work within the body before death" (p. 23). For phantom heroines like Peony, these repressed emotions become so insurmountable that they transcend borders and time and even death itself.

Having to function as a woman in a patriarchal society and to return as a hungry ghost in the Chinese afterlife, Peony is doubly abjected due to her gender and her form as a disembodied soul that lingers between the realm of the living and the dead. Radically marginalised by the culture and society, Peony is relegated to the position of the abject as she is considered as an entity that does not respect boundaries and can threaten and subvert them. As illustrated by Julia Kristeva (1982), the abject is anything that does not "respect borders, positions, rules: the in-between, the ambiguous, the composite" (p. 4). Adding on to this point, Kelly Oliver (2003) puts forth that the abject "must be jettisoned from the borders and placed outside" due to its ability to threaten identities (p. 47). This practice of abjecting women is prevalent in the patriarchal Qing society as it maintains its structure by excluding women from the public sphere. The abjection of women does not end there, as patriarchal gender norms are 
believed to persist even in the afterlife (Zeitlin, 2007). It may seem as if Chinese women will never be able to gain autonomy and reclaim their subjectivities within the patriarchal construct. As such, I intend to examine how Peony is able to articulate her voice and reclaim her sense of identity beyond the veil of death through the projections of her abject desires to return to $\mathrm{Wu}$ Ren, to writing, and the semiotic chora. Despite the negative connotations associated with the abject, this study aims to show that the concept of abject can bring about positive transformation to the self and ultimately serve as preconditions to changing, albeit in small ways, rules, laws, regimes to bring about justice and liberty. To this end, it is hoped that Kristeva's analysis of abjection will be able to provide the relevant theoretical underpinnings to analyse the representations and significance of these abject notions of desires in relation to the traditional Chinese context.

\section{LITERATURE REVIEW}

Chinese fiction in English has begun to gain popularity among readers in the past few decades. Some of these popular works of fiction were produced by Chinese women or women of Chinese ancestry. The works of notable women writers like Maxine Hong Kingston, Zhang Ailing and Amy Tan which revolve around issues related to gender and identity have received widespread attention from critics and researchers alike. Some of the existing studies that feature the work of these female writers explore topics that revolve around women's position, voice, and identity.

First, a study by Hsin (2007) examines the conflict that occurs between civilization and desires in Zhang Ailing's short stories. Hsin utilizes feminist, Lacanian and Bakthinian readings to analyse the struggles of characters represented through the conflict between liberation and suppression of their desires. Hsin concludes that this conflict victimizes both men and women. The characters' endeavours to address their desires within the constraints of social demands have been shown to be futile. Through her study, she suggests that the irreconcilable conflict between civilization and desires could be set as one of the criteria to gauge and trace the root cause of the characters' sufferings. A second study by Sun (2009) explores the themes of women's silence and voice in Maxine Hong Kingston's novel, The Women Warrior through an Asian American feminist lens. She argues that women's silence can be interpreted as a symbol of protest or dissent against the patriarchal structure. Additionally, she asserts that women's voices can take on different forms such as through writing and the rewriting of classic literature. Through the interpretation of women's silence and voice in Kingston's novel, Sun concludes that Kingston has managed to subvert the traditional images of Chinese women and break the silence in the history of Chinese Americans through her narrative. A third study by Chen (2014) employs Alison Jagger's socialist feminist perspective to examine the socio-emotional experiences of women in their respective roles as mothers and daughters. Karl Marx's traditional concept of alienation was used to conceptualize the experiences of these women in Amy Tan's novel, The Joy Luck Club. By examining the effects of alienation and oppression, Chen concludes that these women were able to defeat patriarchal rules and rebuild the mother-daughter relationship through the method of storytelling. By sharing their experiences as victims of alienation in a contemporary capitalist patriarchal society, the mothers in The Joy Luck Club were able to bridge the generational gap and form alliances with their daughters. This way, the mothers are able to prevent their daughters from being trapped as a victim in the cycle of alienation and oppression.

In a more recent study by Tope (2015), she discusses the practice of authoritarianism through population control in Singapore and its implications on women's subjectivity. This issue was revealed through the predicaments of a few female characters in Catherine Lim's 
collection of short stories titled Paper Women. In these narratives, the female characters were subjected to sterilization to comply with the state's desires to advance the nation to greater economic heights. In this respect, women are denied control and freedom to their bodies as they are controlled by the patriarchal state. Because these women are commodified and positioned as sacrificial figures for the purpose of economic development, their sexuality is reduced to patriarchally constructed paper agreements. Nevertheless, these women find gendered solidarity amidst their struggles and experience of womanhood in a nation-state dictated by men. The following study which is conducted by Lau (2020), examines the evolving status of Chinese women in selected Chinese literary texts. In his study, he argues that Maxine Hong Kingston's The Women Warrior is a form of subversive writing that signals women's resistance towards Confucian's cult of domesticity and the awakening of the modern woman. By looking at the misogynistic treatment of daughters, women's silence and chastity, as well as the implications of women's transgression, Lau concludes that the influence of modern and humanistic ideologies can aid in the reawakening and emancipation of women.

In addition to this list, there are also a few studies that have been conducted to analyse the works of more recent women writers like Lisa See and YangSze Choo. Zhang's (2017) research on Lisa See's Peony in Love investigates the metaphors of anorexia and their significance in the female character's life. Zhang employs a feminist psychoanalytical framework to analyse the metaphors of anorexia as an imitation of art, a symbol of a failed mother and daughter relationship, and a form of language. The findings of the study reveal that anorexia, although detrimental to the female character, can be read as a form of resistance against the feudal connotations of womanhood. Meanwhile, Dalal's (2020) study on YangSze Choo's The Ghost Bride aims to uncover the perception of reality in relation to the genre of speculative fiction. Dalal conducts the study by examining the male guardian spirit Er Lang, the journey of the female character Li Lan through parallel worlds, as well as the incorporation of specific folklore and mythical beliefs in the novel. In doing so, Dalal concludes that the perception of reality is not only limited to what the eyes can see but also through the eyes of the inner mind.

In relation to the concept of abjection by Julia Kristeva, many studies have been conducted to examine the abject and its implications. However, most of these deal with literary works that centre around the Western context as opposed to the Chinese setting. To date, little attention has been paid to the notion of the abject in Chinese fiction in English. This signifies a gap in the study of the process of abjection in relation to narratives that revolve around the Chinese context. For this reason, the following existing studies will be presented for discussion instead. The first study by Aktari (2010) explores abject representations of repressed female desire and female identity in the feminist rewritings of traditional Gothic narratives. By analysing the concept of the abject in these narratives, Aktari demonstrates how these abject representations can subvert patriarchal ideologies as well as rewrite the history of female sexuality in feminist terms. He concludes that the emergence of postmodernism, which provided a platform for the rewritings of conventional female Gothic narratives by postmodern female Gothic writers, has enabled abject representations of female desire to gain positive characteristics which as a result promises liberation for women.

Another study by Washburn (2014) examines the relationship between abjection and empathy in the 1996 novel Infinite Jest by David Foster Wallace. Her research investigates the blurred boundaries among the selected characters and the consequences which include emotional isolation, hollow identities, and the various quests to fill the voids. Additionally, it analyses the positioning of empathy as the converse of abjection. Washburn concludes in her study that empathy is vital in addressing emotional isolation which stems from the blurred boundaries of abjection. Another scholar Myers (2015) investigates the representations of ageing in the four selected texts by Rosa Montero through the lens of Mikhail Bakhtin's theory 
of heteroglossia and Julie Kristeva's theory of the abject. In this study, Myers examines the effects of cultural constructs of age and ageing, the interpretations of reflections in literal and figurative mirrors as well as the sexual identity of female characters. She concludes that the negative cultural language used to speak of changes in the body and the process of ageing as well as the Western culture's obsession with youth has a direct impact on how the characters deal with the concept of age and their experience of ageing. Hence, individuals should take control of their own narratives as they have a choice to make their stories positive or negative. Ali (2013) highlights the notion of courtly love as parallel to abjection in Samuel Daniel's sonnet sequence, To Delia. Her research investigates the definition of love and sexual desire as portrayed through the sonnets. By analysing the work through Lacan's and Kristeva's psychoanalytical theories, Ali concludes that the persona is an abject lover with narcissistic and egoistical qualities who is more concerned about himself rather than the lady he is wooing. Lastly, a study by Satkunananthan (2015), interrogates the ways in which instances of infanticide and domestic violence in theatre plays unearth issues related to social unrest and phobias in a multicultural, twenty-first century Britain. These abject scenes of brutality are examined closely through Kristeva's psychoanalytical lens. Satkunananthan concludes that these brutal scenes presented casually to the readers are significant in the plays as they disrupt the hegemonic concept of a family and affect the readers psychologically by bringing them back to the heart of humanity's collective fear.

\section{CONCEPTUAL FRAMEWORK OF THE ABJECT}

In Kristeva's interpretation of the abject, she revealed that the construction of a subject's identity would require the child to be detached from the mother's body. She explains that in the beginning, the child is immersed in this maternal space, or what she terms as the semiotic chora. This maternal space is where the child learns to use sound and energy to express its needs and desires. The child at this stage is not yet able to identify itself as distinct from its surroundings. Nonetheless, as this awareness deepens, the child becomes aware of its surroundings and realises that language can be used to point to things outside itself. At this time, the child realises the distinction between the self and the others or alternatively termed as the subject and the object. This point of realisation is what Kristeva terms as the thetic break. It is this detachment from the semiotic chora and its subsequent entrance into the symbolic world of language that marks the starting point for signification and the construction of the child's identity as a subject. As the child steps into the realm of order and language, the first thing that the child abjects is the mother's body. This process of abjection is necessary as explained by Kristeva (1982): “Abjection preserves what existed in the archaism of preobjectal relationship, in the immemorial violence with which a body becomes separated from another body in order to be” (p.10). Adding to this, Kristeva claims that the abject never really leaves the subject. Grosz (1990) articulates that the abject "can never be fully obliterated but hovers at the border of the subject's identity, threatening apparent unities and stabilities with disruption and possible dissolution" (p. 87). It remains in the subject's subconscious mind, threatening to return and disrupt the boundaries of the self. This creates feelings of anxiety within the subject as the incessant hauntings of the abject could affect one's sense of self. Nevertheless, it is this fear of the abject itself that keeps the subject vigilant, as it can be alluring enough to engulf the individual and distort the self. In other words, the semiotic will continue to remain a part of the symbolic in all its communication. For this reason, Arya (2014) posits that abjection is a continuous process that is central to the notion of subjectivity. As such, this continuous process of identification and rejection produces a subject in-process, as the subject is forced to find a balance between these boundaries. In essence, the sense of self is never a 
stable entity but rather an ever evolving one as it continues to be under the threats of invasion and dissolution.

Although Kristeva's focus is mainly on the process of abjection that brings objects into being, the study of the abject can also be read as a social phenomenon. The vastness of the concept of abjection has led to multiple studies and discussions on topics related to the unconscious mind, the operation of language, the oppression of women, the marginalisation of outsiders, the construction of identity, and many more. Therefore, the concept of abjection has been widely studied in the arts, humanities, and social sciences. To begin with, the self, according to social theories, is essentially constructed as something clean, proper, and stable. Mary Douglas (2002) explains that the unclean is anything that is universally shunned, as it is out of place and does not conform to societal norms. Uncleanliness, as Douglas elucidates, is a cultural perception of anything that lies outside of the system and that could cause defilement in a person or a society. As such, societies maintain order by excluding anything that is deemed impure, unclean, or unstable. On this account, anything that falls under the category of the inbetween is considered dangerous and threatening because it is not a part of the system. Kristeva expounds on this argument by suggesting that the abject is constitutive of this notion of the unclean as it is ambivalent and ambiguous in nature. The abject represents a refusal to be classified under any of these divisions and a resistance to unity. For this reason, abjection is deemed as a necessary process for a subject or a society to impose or maintain a state of purity. On this note, Arya (2014) explains that although the process of abjection may arise from a variety of sources, it is still a phenomenon that is "universally resonant" as it is experienced by all cultures (p. 44). The process of abjection is thus not only an individual experience but a collective one as well since social, cultural, and historical aspects have a part to play in the functioning and the development of the self.

In this line of thought, anyone or anything that does not conform to the dominant values will be abjected by society. This is especially evident in societies that undermine women and elevate men. The narcissistic nature of a patriarchal society necessitates this process of abjection in order to clearly delineate boundaries and maintain order in the ruling system. The dichotomized view that men are whole, clean, and proper while women are polluted, sinful, and abject beings have been endorsed through the different religious, social, and cultural discourse over the centuries (Lawless, 2003). Notions of femininity, the maternal, the Other, and any other figures which have been marginalised, excluded, or expelled due to its ambiguous and threatening features are associated with the abject. Meanwhile, notions of masculinity, the paternal, the clean and the proper are associated with the symbolic order. This has led the societies and even women themselves to believe that they are the embodiment of the abject. Patriarchy has thus used this misconstrued narrative as the premise to enforce and rationalise male dominance. Davies (2006), states that "[by] abjecting the weak, the dependent and the feminine", the "coherence and legitimacy of the dominant male " $\mathrm{I}$ " is established ( $\mathrm{p}$. 73). Without these boundaries, the patriarchal system will be in a state of perpetual danger as the abject female figure continues to disrupt the equilibrium of the system. As such, the patriarchal power continues to exert control over women by stifling the emergence and development of female subjectivity. In relation to this, Kristeva (1986) asserts that maintaining sexual difference is imperative for men as they rely on this notion to maintain their self-image. As Sedehi (2014) states, "the more women accept suppression, the bolder men become to belittle them" (p. 57). The idea of women obtaining the phallus by expressing their desires or entering into the symbolic order without the intervention of men would signify chaos and disruption as the reversal of this dichotomy could potentially threaten the stability of the patriarchal system. For this reason, women are reduced to their reproductive function and excluded from knowledge and power (Kristeva, 1986). In essence, to achieve patriarchal monotheism and to maintain this sexual distinction, all forms of women's desires have to be 
repressed. Having said that, Kristeva proposes an alternative approach to address and reconcile women's multiple desires in the symbolic order. She puts forth the importance of embracing the abject in order to create an egalitarian society that celebrates the reconciliation of different women's desires in the symbolic order. As such the emergence of a utopian society is only possible when the abject is embraced rather than expelled or excluded.

\section{REPRESENTATIONS OF ABJECT DESIRE}

The teachings of Confucianism have had a significant influence on the people of traditional China. Adopted as the official state ideology ever since the establishment of the Han dynasty, Confucianism is perceived as a way of life or a system of values that can be applied to every aspect of people's lives. The Confucian philosophy underwent several expansions throughout the dynasties and this evolution has had a considerable impact on existing social structures like family and marriage. Consequently, the lives of many women were affected, as the ruling dynasties adopted the gendered ideas of Confucianism to further reinforce the Chinese patriarchal governance and society (Shen \& D'Ambrosio, n.d.). The revival of the Confucius doctrine through the Neo-Confucians ever since the Song dynasty led to the decline of women's social status (Littlejohn, 2017). Thereafter, stringent moral codes that placed emphasis on women's conduct and their social roles were enforced through the publications of multiple commentaries and biographies (Mann, 1997). These writings which highlighted portrayals of women who exemplified feminine virtues, and criticised unruly women who indulged in their selfish demands were aimed at propagating Confucius rules of propriety. An example of such writing was titled Admonitions for Women. This text which was written by Ban Zhao (48-116 C.E.) outlined the importance of abiding by the "Four Virtues" which include proper speech, virtue, conduct, and countenance.

On the third day after the birth of a girl...lay the baby below the bed [to] plainly indicate that she [is] lowly and humble and should regard it as a prime duty to submit to others...give her a spindle with which to play [signifying] that she should accustom herself to labor and consider it a prime duty to be industrious. Let a woman modestly yield to others; let her put others first, herself last. Should she do something good, let her not mention it; should she do something bad, let her not deny it. Let her bear contempt; let her even endure when others speak or do evil to her. Always let her seem to tremble and to fear.

(Zhao, as cited in Bary and Bloom, 1999, p. 822)

In addition to these four feminine virtues, women were expected to adhere to the "Three Obediences," which clearly laid out a daughter's submission to her father and brothers, a wife's submission to her husband, and a mother's submission to her son when widowed. Furthermore, central to Confucianism is the concept of filial piety whereby the emphasis is placed on the parent-child relationship. This was explained by Yao (2000) in his book titled An Introduction to Confucianism.

As a traditional doctrine that came into being in a patriarchal society, Confucianism held a low opinion of women. In the family, the primary virtues of a young woman were considered to be her filial piety towards parents and parents-in-law, assistance to her husband and education of her children.

In this regard, a women's position was always perceived as inferior and in relation to the male figures in her family. A women's individual identity bears little to no significance in the Chinese patriarchal society, since her role in the social order was to ensure the well-being and success of her male counterparts (Lau, 2020). Having said that, a woman's perspectives, needs, and feelings were therefore viewed as insignificant and negligible since she was 
expected to be selfless, passive, and compliant. A woman who expressed feelings of love and desire was seen as attempting to exercise free will for personal inclinations. This could be perceived as a challenge to the social and cultural mores of traditional Chinese society as these notions were not in line with Confucian views of femininity and propriety (Ko, 1995). Furthermore, moral conventions dictate that the union of a man and woman should be decided by one's parents and arranged by a matchmaker (Gao, 2003). Since the virtue of filial piety is central to the teachings of Confucianism, engaging in passionate love without the presence of a family framework would result in moral condemnation (Santangelo, 2000). This would not only bring dishonour and shame to the individual but also to the family. To this end, Kristeva's theory of the abject can be used when analysing the notion of forbidden desire in a Confucian based patriarchal society as these are primally repressed but familiar emotions that could presumably threaten the boundaries of a civilised society.

For Peony, the trace of abject desire is made apparent when she first catches sight of a young scholar called Wu Ren. The sight of Wu Ren during their first encounter stirs a sense of fear and excitement in her, but she is not allowed to display her emotions. She has, after all, been taught by her mother to repress her emotions and desires, so she says: "My heart pounded - from fear, from excitement, from the sheer extraordinariness of the situation. This man had to be one of my father's friends. I had to be gracious yet maintain decorum" (See, 2007, p. 19). Her feelings for $\mathrm{Wu}$ Ren intensify when he invites her to meet again for the second time. As a young maiden from an affluent family, Peony is expected to adhere to the social codes of her time. Since Peony is already betrothed to someone else, so she is not supposed to secretly meet up with Wu Ren. Peony's internal conflict is made apparent in the following line: "I felt torn between the desire to meet my stranger again tonight and the lessons that had been drilled into me since childhood about how I should behave" (See, 2007, p. 24). However, the desire to meet Wu Ren overpowers her ability to discern and judge. Peony craves an emotional reunion with Wu Ren but is also fearful of his presence and her actions. She knows that her actions if discovered, may bring disapproval from her family. Peony's struggle to overcome her abject desire is evident in the following line: "A girl couldn't do anything worse than bring embarrassment and disgrace on her family in this way, but I was foolish and stupid and my mind was dulled by desire" (See, 2007, p. 48). Peony is clearly aware of the repercussions that come along with her actions. The moment she engages herself in a conversation with Wu Ren, she is already stepping over the cultural boundaries, laws, and rules of her existence. Yet, she fails to withhold herself from succumbing to her emotions and desire.

According to Kristeva (1980), anything that threatens the "identity, system and order" is repressed and cast aside in the same semiotic space as the mother (p. 4). In this respect, Peony's desire to be with $\mathrm{Wu}$ Ren is viewed as abject as this form of behaviour does not respect the social codes of her society. Confucian moral codes place a strong emphasis on the cultivation and control of desires and drives. This form of purification reflects the need of the socio-symbolic order to expel elements that are deemed as impure in order to produce clean and proper subjects (Covino, 2004). For this reason, any form of attitudes or behaviour associated with these emotions and desires were viewed negatively and were not traditionally accepted by the Chinese society (Santangelo, 2006). This creates an internal conflict within Peony as she is placed in opposition to the patriarchal symbolic order. The tension that arises due to this conflict is similar to the tension that a child experiences upon entering the symbolic realm. For Kristeva, in order to gain access into the symbolic realm, the child would unconsciously repress the rhythmic drives of the semiotic chora. The more the child enters the symbolic, the more the child must repress the articulation of the spoken and written word. In a similar vein, Peony has to constantly cast aside her desire to be with Wu Ren in order to take up a position as a social being in the patriarchal symbolic order. Peony's confrontation with her abject desire forces her to confront the boundary that separates what does and does not 
constitute her being. This evokes simultaneous reactions of fear and longing within her. She fears the consequences that may befall her and her family. Yet, she longs for him. The overbearing desire to be with $\mathrm{Wu}$ Ren is ceaselessly challenging the borders of her selfhood. She is conflicted within as she has been taught to observe the gender roles imposed by the patriarchal symbolic order. Chinese women were expected to portray themselves as passive and submissive figures. As a female figure, Peony is rendered an object in a patriarchal society, and thus she is expected to repress her desires. Thus, to have desires and to act upon these desires is to claim the subject position and to go against the gender dichotomy of the patriarchal symbolic order (Aktari, 2010). Since Peony occupies a subordinate position in a patriarchal society, her abject desire for Wu Ren and her actions are not only a threat to the stable boundaries of herself but also a danger to the patriarchal society.

\section{IMPLICATIONS OF ABJECT DESIRES}

As explained by Kristeva, a confrontation with an abject can be a very unsettling experience. The abject draws and repels its subjects and infects them with its sickening yet irresistible qualities. When the clean and proper body is infected by the abject, the subjective identity is no longer stable. The subject struggles to demarcate the border between the self and others. This internal conflict experienced by the subject is as Kristeva (1980) describes, a "vortex of summon and repulsion" (p. 1). Both reactions affect the subject physically and psychologically. This struggle would eventually lead to the widening of the abyss between the self and other. When this happens, the subject is no longer able to maintain selfhood. Subsequently, the subject may be driven to the utmost form of self-abjection which is self-destruction. For this reason, Kristeva (1982) argues the abject can be a real threat as "it beckons to us and ends up engulfing us" (p. 4). In this sense, it is apparent that abjection can bring deleterious effects to the subject. On this note, See extends her treatment of the abject by focusing on the implications of Peony's abject desire on her physical and psychological states.

Peony's condition is further aggravated when her mother finds out that she had sneaked out of the Women's Chambers. As a result of her actions, she is locked in her room to prepare herself for her wedding. The decision to imprison Peony from a social and cultural standpoint could be seen as an attempt by Peony's mother to protect her from the abject. Since social respectability is highly valued in a Confucian based patriarchal society, Peony's mother will not allow Peony to do anything foolish that may tarnish the family's honour and reputation. This is because Peony's actions are dangerous as they do not, as Kristeva (1982) states, "respect borders, positions, [and the] rules" of a patriarchal society (p. 4). Under these circumstances, Peony starts to become an abject herself as Peony's mother, whom Peony is supposed to identify with, abjects her before she even sees herself as an abject.

Peony is locked away for two months before she is allowed to come out again to have a look at her final wedding gifts. The array of gifts laid out in the hall serve as an impending reminder that her wedding will take place soon. The sight of female members in her family revolts her. Peony's attempt to repress her emotions to hide her disinterest and despair is shown in the following lines:

After so many weeks of solitude, the chatter and competitiveness - all hidden behind the activities of embroidery, calligraphy, and reading poetry - clearly revealed to me the shadow of darkness of the women who lived in the Chen Family Villa. I felt tears gather from the exertion of trying to be a good daughter, of listening and protecting myself from their false concern, and of realizing that this was my life.

(See, 2007, pp. 104-105) 
Unable to identify with her mother and relate to the people around her, Peony is trapped in her own home. Despite the familiarity, she feels as if she does not belong there. She is tired of upholding the image of a filial and submissive daughter. She is reacting to her surroundings in the same way Kristeva (1982) details a person's reaction to the abject:

"I" want none of that element, sign of their desire; "I" do not want to listen, "I" do not want to assimilate it, "I" expel it [...] I expel myself, I spit myself out, I abject myself within the same motion through which "I" claim to establish myself.

Amid all her wedding preparations, Peony experiences the torments of abjection. She is now represented as being in opposition to everyone around her. This imaginary border between her and the rest of her family members portrays the bifurcated existence of the "proper-clean and improper-dirty, possible and impossible" as elucidated by (Kristeva, 1982, p. 72). In concordance with Kristeva's notion of binary of oppositions, Judith Butler (1993) further explicates the complex zones that mark the abject - subject dichotomy:

\begin{abstract}
The abject designates here precisely those "unlivable" and "uninhabitable" zones of social life which are nevertheless densely populated by those who do not enjoy the status of subject, but whose living under the sign of the "unlivable" is required to circumscribe the domain of the subject. This zone of uninhabitability will constitute the defining limit of the subject's domain; it will constitute the site of the dreaded identification against which - and by virtue of which - the domain of the subject will circumscribe its own claim to autonomy and life. In this sense, then, the subject is constituted through the force of exclusion and abjection, one which produces a constitutive outside to the subject, an abjected outside, which is, after all, "inside" the subject as its own founding repudiation.

From a social and cultural standpoint, Peony is now considered to be improper and unclean as she has been contaminated by her undying passion for $\mathrm{Wu}$ Ren. She is forced to exist in a zone dictated by the domain of the subjects. Unable to escape and plagued by her abject desire and longing for Wu Ren, Peony spirals into negativity as she engages in reckless thoughts and behaviour that are harmful to her physical and mental health. She attempts to cope with this form of defilement and refill the empty, violated space by indulging in excess. Left tainted and abjected, she isolates herself and invests her energy in reading, writing and imagining as that is where her interest lies:

I wanted to submerge myself in my feelings. I wanted to bury myself in thoughts of love. I had no way to get out of my marriage, but maybe I could escape from it in the same way I had here in my natal home, by reading, writing and imagining...I had to find something that would not only be meaningful to me but would sustain me for the rest of my life.

(See, 2007, p. 105)

Peony's extreme emotional state and excessive behaviour are a result of her inward abjectification. She can only lead a forfeited existence since she is no longer able to identify herself with anyone in her surroundings. Abjection, as stated by Kristeva (1982), is "elaborated through a failure to recognize its kin; nothing is familiar, not even the shadow of memory" ( $p$. 5). As such, she attempts to submerge herself in her writing project as a means to displace abjection. However, the more she indulges in her writing project, the more her yearning for $\mathrm{Wu}$ Ren intensifies. From the Kristevan lens, her attempt to distract herself from lovesickness has proven to be futile as the more she consumes through reading and writing, the more 'abject' her body becomes.

I worked so hard and ate so little that I began to doubt I had ever met a stranger in the Riding-theWind Pavilion for two nights. Had the poet and I actually left the Moon-Viewing Pavilion to walk along the lakeshore? Was all that a dream or real? It had to be real, and very shortly I would be sent into a marriage with someone I did not love.

(See, 2007, p. 112) 
By wasting life and sinking further into a state of abjection, Peony becomes an embodiment of one of the living dead, existing in between the liminal state of life and death. She now, as Kristeva (1982) elucidates, "beholds the breaking down of a world that has erased its borders: fainting away" (p. 4). The annihilating power of her abject desire manipulates Peony mentally and as such, she is not able to think clearly. Peony experiences miscognition and becomes perplexed as she can no longer make the distinction between the real and the imaginary. This collapse of meaning in her life shows how death is infecting her life, engulfing her in her attempt towards self-destruction. Unable to receive fulfilment, she attempts to exhaust herself and follow in the footstep of her lovesick idol in the opera's plot by starving herself to death.

\begin{abstract}
Visions of love consumed me. What little appetite that had survived my first confinement left me completely. Xiao-qing used to drink half a cup of pear juice each day; I took only a few sips. Not eating stopped being about maintaining control over my life. It even stopped being about my poet and the tumultuous feelings of love and longing I felt were consuming me.
\end{abstract}

(See, 2007, pp. 112-113)

Peony's refusal to ingest food signifies the beginning of her separation from the social order and reveals a space between her self and others. As pointed out by Kristeva (1982), "Food loathing is perhaps the most elementary and most archaic form of abjection" (p. 2). Unable to face and deal with the horror of abjection, she chooses to deprive her body of food. It also represents her attempt to establish autonomy and resistance to the existing social structure that denies her subjectivity.

However, Peony's act of defiance does not last long, as Peony's mother eventually finds out about Peony's obsession with reading and writing and her refusal to ingest food. The family then calls upon the family's diviner and a doctor to cure Peony of her sickly state and obsessive behaviour. They think she is sickly due to the influence of evil spirits. As such, both healers advise the family to make Peony angry, as this form of treatment is believed to be able to relieve Peony from her melancholic condition. For that reason, Peony's mother proceeds to burn all of Peony's books so that she will no longer be able to continue with her writing project. Access to knowledge is deemed as a curse that could invite the presence of evil spirits and as such must be removed from the beholder. Peony's painful ordeal is shown in the following lines:

\footnotetext{
"You can't! They're mine!" I screamed, gathering together as many of the volumes as I could reach, but Mama and Shao were surprisingly strong.

“My project, please Mama," I cried. "I've worked so hard."

"I don't know what you're talking about. You have only one project: to get married," she said, as she swooped up the edition of The Peony Pavilion that Baba had given me for my birthday.
}

I saw a volume of women's writings burn and curl into nothing. My chest heaved with sobs. Shao released me and went back to the bed to gather up the rest of the books.

When she left the room, Mama asked, "Are you angry?"

I was not that. I felt nothing but despair. Books and poems can't keep away hunger, but without them I didn't have a life.

(See, 2007, p. 118)

Although Peony manages to establish a defensive position, it is still not, as Kristeva contends, "radically enough to allow for a secure differentiation between subject and object" (p. 7). As such, representatives of the symbolic order try to cleanse her from excess and abject emotions by purification rituals and treatment. The concept of purification, as shown in this context, is the symbolic order's attempt to protect "cherished classifications" and patriarchal values from any form of contradiction (Douglas, 2002, p. 37). 
Peony's abject love for reading and writing become her only means for survival as she struggles to identify with the symbolic order. To have that remaining purpose taken away from her is to have her subjectivity erased in its entirety. This has proven to have detrimental effects on Peony as the more her abject yearnings intensified, the more her mental condition deteriorates. Although Peony does not expect death to come so soon, she eventually dies of starvation. It is already too late for her to come to her senses as she is now a wandering soul who is bewildered and uncertain of her journey in the afterlife. While hovering around the premises of her natal home, she is horrified to see the state of her body as her corpse is stripped for the final cleansing prior to the burial ceremony:

My first concern was for that part of my soul that would stay with my body. Mama and aunts
stripped my corpse and I saw how horrifyingly emaciated I was. They washed me an uneven
number of times and dressed me in layers of longevity clothes.
(See, 2007, p. 137)

The vision of Peony's own emaciated corpse shocks her, as the body which is lying there among her family members was once hers. To see it in such a depressing state becomes an inherently traumatic experience for her. As she looks at it from above, what was once familiar seems foreign to her and she is traumatically reminded of the destruction that she brought upon her now-deceased body. She becomes the corpse, the cadaver, that which is continuously thrust aside in order to live. In addition to being positioned as abject due to her gender, Peony becomes increasingly abject as a ghost roaming between the world of the living and the dead. Her existence as an ambiguous entity once again relegates her to the position of the abject as her presence disrupts the borders between the natural and the supernatural as well as the human and the non-human.

\section{RECLAIMING IDENTITY THROUGH THE ABJECT}

As shown from the above analysis, confrontation with the abject may have deleterious effects on a subject. Nonetheless, based on Kristeva's theory, abject forces can be used as a semiotic tool to destroy patriarchal ideals that promote hierarchically constructed binary oppositions. When abject forces make their presence felt in the symbolic realm, they are upsetting and subverting the established norms of the dominant structure. In other words, when the repressed and the silenced are given the voice to make their presence felt, they are already asserting their position as a subject which was denied by the dominating values of the symbolic order. By reuniting with the semiotic influences, the individual is no longer passive and repressive as defined by the language of the paternal law. When this happens, the individual becomes a subject in process whose subjectivity is never fixed but a work-in-progress. In relation to this, Kristeva's theory promotes the unity of both the semiotic and symbolic forces in order to become a subject in process. In Kristeva's view, the symbolic can never be completely devoid of the semiotic. The semiotic is imperative in the development of self as it helps the subject to produce meaning in the symbolic order. Without the semiotic, the symbolic realm would be devoid of meaning. In this respect, when subjects are forced to only identify with either one of these realms, their borders of self will be threatened. This can be seen through the portrayal of patriarchal symbolic structures whereby women and representations of their desires are defined as passive and repressive. As a result, women from these oppressive structures are marginalised, excluded and expelled from the symbolic order. In addition, women are relegated to the position of an abject and denied the position of a subject. For this reason, Kristeva refuses the dominance of either one of these realms. Instead, she puts forth the possibility of a plural identity which she terms as the subject in-process. By embracing a plural identity, the subject in process embraces both the semiotic and the symbolic influences, which liberates the 
individual from having to adhere to a stable, fixed identity. This approach is revolutionary as it challenges the conventional discourse of patriarchy and puts forth a new method of defining subjectivity.

The second part of the plot showcases Peony's existence as a ghost. Trapped in between the world of the dead and the living, Peony is not able to cross over to the realm of the afterworld as her funeral rites were not executed completely. However, upon being advised by Peony's grandmother, Peony realises that despite being dead, there is still a possibility of having her funeral rites completed and making herself heard by influencing the living through her ghostly abilities.

\begin{abstract}
"Are you saying I could also get my tablet dotted?"
Grandmother leaned forward and took my hand in hers. "You should hope for that to happen, because then you'll come back here and become an ancestor. But you won't be able to make it happen. You'll have a lot of tricks that you can use with people in the earthly realm to get them to do what you want them to do, but you will be powerless when it comes to your tablet. Remember all the ghost stories you heard as a little girl? There are a lot of different ways people become ghosts, but if all those creatures who didn't have their tablets dotted could force humans to complete this task, there wouldn't be very many ghost stories, would there?"
\end{abstract}

(See, 2007, pp. 197-198)

Peony eventually develops a sense of agency after establishing ties with the semiotic figure, which is represented through Peony's grandmother. Through this semiotic reunion, Peony is able to learn from her grandmother on how to utilise her otherworldly abilities as an abject entity to navigate between the realm of the living and the afterlife. She comes to the realisation that her ghostly abilities would allow her to manipulate the living into helping her to address her abject desires for Wu Ren and writing. The semiotic has thus helped Peony to realise what was thought to be impossible for her upon her death.

As Peony still has profound desires for $\mathrm{Wu}$ Ren and her writing project, she tries to exert her ghostly influence on Ren's second wife. She is hoping that her second sister-wife will be able to fulfil her desires on her behalf. However, her actions cause the death of the second sister-wife instead. Filled with shame, guilt and regret, Peony goes into exile. This reclusive behaviour can be read as an attempt to turn away from the symbolic. Upon her second sisterwife's death, Peony no longer has the avenue to channel her abject desires. Writing through her second sister-wife becomes a temporary salvation to cope with the grim actualities of her existence as a ghost. However, now that her second sister-wife is dead, she is faced with the challenge of coping with the loss of her sister-wife due to her selfishness and the loss of her abject desire to write. In brief, Peony's ordeal can be summarised in Kristeva's (1992) following lines, "Knowingly disinherited of the Thing, the depressed person wanders in pursuit of continuously disappointing adventures and loves; or else retreats, disconsolate and aphasic, alone with the unnamed Thing" (p. 13). Unable to find a compensation for the loss, she wanders aimlessly until the day she encounters her grandmother and mother who told her stories about the past. Peony learns about her grandmother and mother's love for freedom and desire for writing, the sacrifices that they had to make, the sufferings endured, and the courage displayed by the women in order to be heard. Upon learning the truth, Peony's mother urges her to make amends and complete her writing project.

\footnotetext{
“Go ahead,” Grandmother urged. "Tell her why we're really here.”

Mama took a deep breath. "You need to finish your project," she said. "It won't be the scribble of a desperate woman on a wall. Your father and I, your grandmother, your whole family - those here in the earthly realm and all the generations of ancestors who watch out for you - will be proud of you".

(See, 2007, p. 330)
} 
Under the guidance of both her grandmother and mother, Peony manages to influence Ren's third wife with her limited ghostly abilities as a way of showing her endearing love for Ren and as means to complete her writing project on her behalf. By reuniting with the semiotic, Peony regains the will to put her past behind and return to writing. In this respect, the semiotic functions as a shelter for Peony as she deals with feelings of guilt and remorse. Additionally, the maternal space that Peony takes shelter in provides her with the support to return to the symbolic realm. In this sense, this maternal reunion seems to benefit Peony greatly as it finally gives her a voice and leads her towards her long-awaited spiritual release:

The Three Wives' Commentary was published at the end of winter in the thirty-second year of Emperor Kangxi's reign in what would have been my forty-fifth year in the earthly realm. It was an immediate and enormous success. To my amazement and unabashed delight, my name - and those of my sister wives - became known across the country.

(See, 2007, p. 368)

As Peony renews her bond with the repressed maternal force, she is reconnected with her past, which leads to her self-awakening. This maternal bond shared between Peony and both her mother and grandmother, simultaneously unsettles and subverts the social order as it allows for an alternative space where women can unite and be free from patriarchal values and oppression. With their love, encouragement, and support, Peony regains the courage to pick up writing again and seek reparation for her wrongdoings. In addition, Ren realises that Peony's funeral rites were not completed accordingly and proceeds to complete them for her. With that, Peony eventually redeems her voice and achieves spiritual release. In Kristeva's terms, Peony is finally able to reclaim her subjectivity as a subject in process by making her voice heard within the symbolic realm. This is in line with Kristeva's ethics that call for the acceptance of the symbolic order and its deficiencies through the preservation of the maternal space and the celebration of its subversive nature within the system.

\section{CONCLUSION}

As a historical fiction, Peony in Love calls attention to the sufferings that Chinese women had to endure in a feudal Chinese society. Oppressed by the dominant patriarchal system, these women were abjected due to their gender and were forced into a lifetime of submission. Women regardless of their backgrounds were silenced throughout their lives and denied the right and avenue to express their subjectivities. The subjugation of women extends beyond death, and this persists even in the Chinese afterlife. Under these social and cultural constraints, it may seem like women are destined to be trapped in a lifetime of oppression. However, in this novel, See presents a narrative where the protagonist, Peony, fights against the imprisoning rules of the patriarchal structure. In this respect, this paper presents the means to study the abject, its implications and functions in the Chinese cultural context. The abject is often viewed negatively due to its ability to threaten the social order and bring about rupture to the dominant system. Nonetheless, in this novel, the abject is used as an agency to subvert Chinese patriarchal and cultural norms. Peony's abject desire for Wu Ren and writing may have cost her her life, but this did not stop her from seeking to be heard. By reuniting with the maternal figures in her family, she is able to learn lessons about life that she was not able to learn while she was alive and regain the courage to pursue her writing project through her sister wives. The abject maternal force which was perceived as a threat to one's subjectivity in the theory of abjection ironically became the catalyst that enabled Peony to rediscover her path. As a result, this form of female solidarity, coupled with Peony's persistence and unwavering love for Wu Ren and writing, eventually became the agencies that enabled her to articulate her voice and achieve 
spiritual liberation. To this end, it is proven that the abject can bring about positive transformations to abject identities despite its ambiguous and transgressive qualities.

\section{REFERENCES}

Aktari, S. (2010). Abject representations of female desire in postmodern British female gothic fiction [Doctoral dissertation, Middle East Technical University]. https://etd.lib.metu.edu.tr/upload/12612288/index.pdf

Ali, H. (2013). The abject lover of the courtly love era. 3L: The Southeast Asian Journal of English Language Studies, 19(3), 11-19. https://ejournal.ukm.my/31/article/view/1564

Arya, R. (2014). Abjection and representation. Palgrave Macmillan.

Butler, J. (2011). Bodies that matter: On the discursive limits of sex. Routledge.

Chen, Y. (2014). From alienation to connection: The theme of alienation analyzed from a socialist feminist perspective in Amy Tan's The Joy Luck Club [Master's thesis, Dalarna University]. Dalarna University English Department Degree Thesis Autumn 2014. http://www.divaportal.org/smash/get/diva2:788167/FULLTEXT01.pdf

Ciarcinska, K. (2019). Objectification of women in China. Research Gate, 104-115. https://www.researchgate.net/publication/343697033_Objectification_of_Women_in_China

Covino, D. C. (2004). Amending the abject body: Aesthetic makeovers in medicine and culture (SUNY series in Feminist Criticism and Theory). State University of New York Press.

Dalal, S. (2020). The many perceptions of reality in search of the self: Reading Yangsze Choo's The Ghost Bride. Southeast Asian Review of English, 57(1), 21-36. https://doi.org/10.22452/sare.vol57no1.4

De Bary, W. T., \& Bloom, I. (Eds.). (1999). Neo-Confucian education. In Sources of Chinese tradition: From Earliest Times to 1600 (2nd ed., Vol. 1, pp. 800-837). Columbia University Press.

Douglas, M. (2002). Purity and danger: An analysis of concepts of pollution and taboo. Routledge.

Gao, X. (2003). Women existing for men: Confucianism and social injustice against women in China. Race, Gender and Class, 10(3), 114-125. https://www.jstor.org/stable/41675091

Grosz, E. (1990) The body of signification. In J. Fletcher \& A. Benjamin (Eds.), Abjection, melancholia, and love: The work of Julia Kristeva (pp. 80-103). Routledge.

Hsin, L. W. (2007). A theoretical study of Zhang Ailing's short story collection Chuanqi. ProQuest LLC. https://core.ac.uk/download/pdf/161528487.pdf

Ko, D. (1995). Teachers of the inner chambers: Women and culture in seventeenth-century China. Stanford University Press.

Kristeva, J. (1986). The Kristeva reader (T. Moi, Ed.). Columbia University Press.

Kristeva, J., \& Roudiez, L. (1982). Powers of horror: An essay on abjection (European perspectives series) (Reprint ed.). Columbia University Press.

Kristeva, J., \& Roudiez, L. (1992). Black sun (Reprint ed.). Columbia University Press.

Lau, C. S. G. (2020). The evolution of Chinese women: From Confucian obligations to modern resistance. In K. Chan \& C. Lau (Eds.), Chinese Culture in the 21st Century and Its Global Dimensions (Vol. 2, pp. 316). Springer. https://doi.org/10.1007/978-981-15-2743-2_1

Lawless, E. J. (2003). Woman as abject: Resisting cultural and religious myths that condone violence against women. JSTOR, 62(4), 237-269. https://www.jstor.org/stable/1500319

Li, E. J. (2017). Narrating "Otherness": (National) abjection as literary and American subjective crises in Maxine Hong Kingston's The Woman Warrior [Unpublished Bachelor's thesis]. University of Michigan. https://sa.umich.edu/content/dam/english-assets/migrated/honors_files/Li\%20Thesis.pdf

Li, X. (2009). Gender and textual politics during the Qing dynasty: The case of the Zhengshi ji. Harvard Journal of Asiatic Studies, 69(1), 75-107. https://doi.org/10.1353/jas.0.0012

Littlejohn, L. J. (2017). Confucianism: How Analects promoted patriarchy and influenced the subordination of women in East Asia. Young Historians Conference. Published. https://pdxscholar.library.pdx.edu

Mann, S. (1997). Precious records: Women in China's long eighteenth century. Stanford University Press.

Montashery, I. (2012). Virginia Woolf's new intellectualism in relation to the construction of a third gender based on desire in her selected works. Universiti Putra Malaysia.

Myers, K. K. (2015). The body beautiful and the abject: A look into the manifold mirror of age. [Doctoral dissertation, The University of Alabama]. University of Alabama Institutional Repository. https://ir.ua.edu/handle/123456789/2561

Oliver, K. (2003). The crisis of meaning. In Lechte, J. \& Zournazi, M. (Eds.), The Kristeva Critical Reader (36-54). Edinburgh University Press.

Santangelo, P., \& Guida, D. (2006). Love, hatred, and other passions: Questions and themes on emotions in Chinese civilization. Brill. 
Satkunananthan, A. H. (2015). The baby's not for burning: The abject in Sarah Kane's Blasted and Helen Oyeyemi's Juniper's Whitening. 3L: The Southeast Asian Journal of English Language Studies, 21(2), 17-29. https://doi.org/10.17576/31-2015-2102-02

Sedehi, K. T., \& Talif, R. (2014). Speaking characters in possessing the secret of joy. 3L: The Southeast Asian Journal of English Language Studies, 20(02), 55-66. https://doi.org/10.17576/31-2014-2002-05

See, L. (2007). Peony in love. Bloomsbury Publishing.

Sheikh, F. A. (2017). Subjectivity, desire and theory: Reading Lacan. Cogent Arts \& Humanities, 4(1), 1-12. https://doi.org/10.1080/23311983.2017.1299565

Shen, L., \& D'Ambrosio, P. (n.d.). Gender in Chinese philosophy. Internet Encyclopedia of Philosophy. Retrieved July 17, 2021 from https://iep.utm.edu/gender-c/

Sun, S. (2009). Interpreting silence and voice in Maxine Hong Kingston's The Woman Warrior: Memoirs of a girlhood among ghosts [Master's thesis, University of Tampere]. Post Gradu Thesis, Spring 2009. https://trepo.tuni.fi/bitstream/handle/10024/80887/gradu03769.pdf

Theiss, J. M. (2002). Femininity in flux: Gendered virtue and social conflict in the Mid-Qing courtroom. In S. Brownell \& J. N. Wasserstrom (Eds.), Chinese femininities/Chinese masculinities: A reader (pp. 47-64). University of California Press.

Tope, L. R. (2017). Women and the authoritarian state: The Southeast Asian experience. In G. V. S. Chin, \& M. K. Daud (Eds.), The Southeast Asian woman writes back: Gender, identity and nation in the literatures of Brunei Darussalam, Malaysia, Singapore, Indonesia and the Philippines (pp. 71-88). Springer. https://doi.org/10.1007/978-981-10-7065-5

Washburn, E. (2014). Abjection and empathy: The shared spaces and blurred boundaries of Infinite Jest [Master's thesis, Georgia State University]. ScholarWorks@ Georgia State University. https://scholarworks.gsu.edu/english_theses/171

Yao, X. (2000). An introduction to Confucianism. Cambridge University Press.

Zeitlin, J. T. (2007). The phantom heroine: Ghosts and gender in seventeenth-century Chinese literature. University of Hawaii Press.

Zhang, N. (2017). Metaphors of Anorexia-Analysis of Peony’s starved-for-love self in Lisa See's Peony in love. Journal of Literature and Art Studies, 7(6), 663-669. https://doi.org/10.17265/2159-5836/2017.06.004 